\title{
A prospective study of morbidity patterns in a petroleum refinery and chemical plant
}

\author{
Shan P Tsai, Catherine M Dowd, Sally R Cowles, Charles E Ross
}

\begin{abstract}
This study examined the morbidity experience from 1981 to 1988 of a prospective cohort of 3422 refinery and petrochemical plant employees from the Shell Deer Park manufacturing complex. The morbidity data for this study, which include all illness and absence records in excess of five days, were extracted from the morbidity section of the Shell health surveillance system. Standardised morbidity ratios (SMRs) of disease prevalence in this cohort were calculated using an internal comparison group of all manufacturing employees of the Shell Oil Company. Among production employees, the overall morbidity was statistically significantly higher $(S M R=109)$ than that of the comparison group. Illness due to hypertension $(S M R=144)$, haemorrhoids $(S M R=149)$, diseases of the nervous system $(S M R=120)$, respiratory system $(S M R=108)$, and digestive system $(S M R=117)$ were also raised for this group. The increased risk due to these medical conditions does not appear to be associated with occupational factors. Lymphatic and haematopoietic tissue neoplasms were raised $(S M R=124)$, but were based on only four cases.
\end{abstract}

In the past 15 years, many epidemiological mortality studies of the petroleum industry have been conducted to characterise the health of a specific working population..$^{1-9}$ Although the diagnoses on death certificates may not be $100 \%$ accurate, the use of mortality as an index of health has several advantages: deaths are well defined, reliable, and consistently recorded, and such information is readily available. Most serious ill health associated with potential occupational hazards will, further-

Shell Oil Company, Corporate Medical Department, PO Box 2463, Houston, Texas, USA 77252-2463 S P Tsai, C M Dowd, S R Cowles, C E Ross more, be ultimately reflected in excess mortality. One problem in studying deaths, from a prevention point of view, however, is that the risk of a current exposure may not manifest itself for 20 to 30 years.

Morbidity data are routinely collected as a part of industrial health surveillance programmes in the United States to detect potential adverse health effects due to environmental hazards or personal risk factors. ${ }^{10}$ The morbidity data can provide information complementary to the mortality study and is invaluable for assessing questions on the health of employees.

Depending on the specific diseases considered, the morbidity experience of a working population can be an important measure of the health effects of environmental or occupational conditions. Unlike mortality data, morbidity data can be used to identify medical conditions that may not result in death. This is especially important for diseases (including cancers) that have a high survival rate. Furthermore, because deaths are often preceded by morbidity events, most associations between occupational factors and a death due to illness should be apparent from morbidity experience. Although general morbidity patterns among employees in the petroleum industry have rarely been reported, ${ }^{11}$ some occupational studies have determined morbidity experience through company medical records, ${ }^{12}$ group health insurance claims, ${ }^{13}$ and various health surveillance registries. ${ }^{14}{ }^{15}$ Evaluations of morbidity in these studies were based on an internal comparison group by contrast with the general population used in most occupational mortality studies.

This morbidity study was based on a cohort of male employees who worked at the Shell Deer Park refinery and chemical plant during the period 1 January 1981 to the end of 31 December 1988. The Deer Park facility has been in operation since 1929 and currently handles substances such as benzene, 1,3-butadiene, fuels, oils, lubricants, isopropyl alcohol, epichlorohydrin, polynuclear aromatics, hydrogen sulphide, and epoxy resins. The objective of this study was to examine the patterns of morbidity in these employees to identify major differences from the total Shell manufacturing population that might 
help to enhance existing prevention efforts. Also prevalences of certain health risk factors (smoking, high blood pressure, hypercholesterolaemia, and obesity) were calculated to evaluate the differences in health habits between Deer Park and the comparison population.

\section{Material and methods STUDY POPULATION}

A prospective cohort study design was used to examine the morbidity experience of employees at the Shell Deer Park refinery and chemical plant. The study population included all full time male employees who worked at the Deer Park manufacturing complex (DPMC) during the period 1 January 1981 to the end of 31 December 1988 for at least one day. Everyone was classified as either a production or staff employee. Production employees included operators, maintenance personnel, testers, laboratory assistants, lorry drivers, and equipment operators. Staff employees included the foremen and supervisors of operations and maintenance, as well as all office employees. The cohort members were identified from the Shell Health Surveillance System (HSS), which has been in operation since $1979 .{ }^{16}$ The total study population numbered 3422 . This population was dynamic, with individual workers entering the observation period (1981-8) at various times and remaining for varying periods. Currently this complex employs about 2400 persons.

\section{MORBIDITY DATA}

Morbidity data for this study were extracted from the morbidity section of the HSS, which includes all illness absence events in excess of five days. Overall, only $5 \%$ of all illness absence episodes were reported to be work related. As records of absences are originally from personnel and payroll systems, the reporting of absence is virtually complete. The policy of sick leave is consistent across facilities and work classification. Ninety per cent of the morbidity reports had written statements by a physician identifying the reason for absence. The causes of morbidity were coded according to the international classification of diseases ninth revision clinical modification (ICD 9-CM).${ }^{17}$ Only the primary cause was used in the analysis.

A morbidity prevalence event in this study was defined as occurring when an employee had a specific diagnostic condition that resulted in an absence of more than five days during the eight year period from 1981 to 1988. Only one prevalence event per employee was counted in any given diagnostic category during this period. A prevalence of one was used regardless of the number of times that a single specific diagnostic condition occurred in the same person. Absences during the study period as well as newly diagnosed conditions are both included, providing a period prevalence. If an employee had absences from two different diagnostic categories during this period, two prevalence events (one for each diagnostic category) would be recorded. Thus, prevalence measures the number of persons with the condition during the study period rather than the total number of occurrences or severity of that condition in the cohort.

\section{SELECTED DISEASE RISK FACTORS}

The data for risk factors were derived from the HSS, which contains all employee preplacement and annual periodic medical examinations done since 1 January 1978 . The most current examination data were used; $70 \%$ of these were done in 1984-8.

Smoking history was used to determine whether an employee is a current cigarette smoker. Raised cholesterol concentration was defined as a value equal to or greater than $200 \mathrm{mg} / \mathrm{dl}$. Raised blood pressures were diastolic blood pressure readings equal to or greater than $90 \mathrm{~mm} \mathrm{Hg}$ or systolic blood pressure readings equal to or greater than $140 \mathrm{~mm} \mathrm{Hg}$. Obesity was defined as body mass index $\left(B M I=\right.$ weight $(\mathrm{kg}) /$ height $\left.^{2}(\mathrm{~m})\right)$ greater than or equal to $27 \cdot 2$. This value represents $20 \%$ more than ideal body weight based on the National Institutes of Health Consensus Development Panel recommendations. ${ }^{18}$

\section{ANALYTICAL METHODS}

Person-years at risk were accumulated for each employee beginning 1 January 1981 or the date of hire, whichever was later, and ending at the closing date of study (31 December 1988), the date of retirement, the date of transfer, the date of death, or the date of termination, whichever was earlier. The number of years contributed by each employee was classified by age (less than $30,30-39,40-49,50-59$, or 60 and over) and work classification (production or staff). The morbidity experience of this cohort was compared with that of an internal comparison group, defined as male employees at all 14 Shell manufacturing locations (including Deer Park) during the study period. Workers from DPMC made up $27 \%$ of the comparison population. The expected numbers of morbidity events were calculated from the age and cause specific morbidity rates of the internal comparison group for each work classification. Standardised morbidity ratios (SMRs) were computed as the ratio of the observed to the expected number of morbidity events for each cause of interest. Significance tests were based on the assumption that the observed number of morbidity events follows a Poisson distribution. ${ }^{19} \mathrm{~A}$ two sided test of significance was used. Because most of the study cohort $(80 \%)$ and the comparison group $(85 \%)$ was white, SMRs in this study were not adjusted for race. 


\section{Results}

The study population included all male employees (1986 production and 1436 staff) who ever worked at Deer Park from 1 January 1981 to 31 December 1988 (table 1). The total number of person-years of observation were 12162 and 8028 for the production and staff groups respectively. The average number of years of observation was $6 \cdot 1$ for production employees and 5.6 for staff employees and the average total duration of employment was 15.9 and 22.5 years respectively. About $74 \%$ of production employees were hired after 1970 compared with $41 \%$ of staff employees (table 2).

Table 3 presents observed and expected morbidity prevalence and standardised morbidity ratios (SMRs) for the entire study population. Overall, 4079 morbidity prevalence events were observed and 3825 were expected, resulting in a statistically

Table 1 Cohort statistics of employees by work classification 1981-8

\begin{tabular}{lcc}
\hline & $\begin{array}{l}\text { Production } \\
\text { workers }\end{array}$ & Staff \\
\hline No studied & 1986 & 1436 \\
No of person-years observed & 12162 & 8028 \\
Average years of age at entry & 37.6 & 42.9 \\
Average years of follow up (1981-8) & $6 \cdot 1$ & $5 \cdot 6$ \\
Average total duration of employment $(y)$ & 15.9 & 22.5 \\
\hline
\end{tabular}

Table 2 Year of hire by work classification

\begin{tabular}{|c|c|c|}
\hline & Production workers & Staff \\
\hline Year of hire & No $(\%)$ & No $(\%)$ \\
\hline $\begin{array}{l}\text { Before } 1970 \\
1970-4 \\
1975-9 \\
1980-4 \\
1985 \text { and after }\end{array}$ & $\begin{array}{c}515(25 \cdot 9) \\
291(14 \cdot 6) \\
836(42 \cdot 1) \\
279(14 \cdot 1) \\
65(3 \cdot 3)\end{array}$ & $\begin{array}{c}849(59 \cdot 1) \\
177(12 \cdot 3) \\
170(11 \cdot 9) \\
152(10 \cdot 6) \\
88(6 \cdot 1)\end{array}$ \\
\hline Total & $1986(100 \cdot 0)$ & $1436(100 \cdot 0)$ \\
\hline
\end{tabular}

significant SMR of 107. Of all the causes of morbidity examined, only haemorrhoids $(S M R=148)$, hypertension (SMR $=140)$, and unknown and all other causes $(S M R=180)$ showed a statistically significant increased morbidity prevalence among the study population. The SMRs for endocrine, nutritional, and metabolic diseases $(S M R=115)$, disorders of the nervous system $(\mathrm{SMR}=114)$, and other disorders of the circulatory system $(S M R=122)$ were also raised, but were not statistically significant. Among other disorders of the circulatory system, the most common diagnoses were phlebitis and thrombophlebitis, varicose veins, atherosclerosis, and other disorders of arteries and arterioles.

Table 4 examines SMRs for employees by work classification. Among production employees, statistically significant excesses of morbidity were seen for all causes (SMR $=109)$, disorders of the nervous system $(S M R=120)$, hypertension $(S M R=144)$, haemorrhoids $(S M R=149)$, disorders of the respiratory system $(S M R=108)$, disorders of the digestive system $(S M R=117)$, and unknown and all other causes $(S M R=173)$. Of the morbidity events from unknown and all other causes, $99 \%$ had no diagnostic information due to the lack of statements by a physician identifying the reason for the absence.

Among staff employees SMRs were raised for several medical conditions; however, only the SMR for unknown and all other causes $(S M R=189)$ was statistically significant. As was the case for production employees, most of these prevalence events had unknown causes. The disorders of the musculoskeletal system $(S M R=63)$ and injury and poisoning $(S M R=67)$ were significantly lower than in the comparison population.

Table 5 presents SMRs for categories of neoplasms. Among production employees, SMRs were

Table 3 Observed morbidity and standardised morbidity ratios (SMRs)

\begin{tabular}{|c|c|c|}
\hline Cause of morbidity (ICD-CM 9th revision codes) & Obs & $\operatorname{SMR}(95 \% C I)^{\star}$ \\
\hline $\begin{array}{l}\text { All causes }(000-999) \\
\text { Infectious and parasitic diseases }(000-139) \\
\text { All neoplasms }(140-239) \\
\text { Endocrine, nutritional, and metabolic diseases }(240-279) \\
\text { Mental disorders }(290-319) \\
\text { Nervous system }(320-389) \\
\text { Heart disease }(390-399,410-414,420-429) \\
\text { Hypertension }(400-405) \\
\text { Cerebrovascular disease }(430-438) \\
\text { Haemorrhoids (455) } \\
\text { Other circulatory system disorders }(440-448,450-454,456-459) \\
\text { Respiratory system }(460-519) \\
\text { Digestive system }(520-579) \\
\text { Genitourinary system }(580-629) \\
\text { Skin and Subcutaneous tissue (680-709) } \\
\text { Musculoskeletal system (710-739) } \\
\text { Symptoms and ill-defined conditions }(780-799) \\
\text { Injury and poisoning ( } 800-999) \\
\text { Unknown and other causes }\end{array}$ & $\begin{array}{r}4079 \\
132 \\
101 \\
55 \\
111 \\
208 \\
119 \\
90 \\
8 \\
72 \\
46 \\
725 \\
442 \\
152 \\
114 \\
448 \\
124 \\
717 \\
415\end{array}$ & $\begin{array}{c}107(103-110) \\
99(83-117) \\
108(88-132) \\
115(87-150) \\
96(79-115) \\
114(99-131) \\
99(82-119) \\
140(112-172) \\
61(26-124) \\
148(116-186) \\
122(90-164) \\
105(98-113) \\
111(111-122) \\
101(85-118) \\
103(85-123) \\
93(85-102) \\
94(78-113) \\
93(86-100) \\
180(163-198)\end{array}$ \\
\hline
\end{tabular}

$\star 95 \% \mathrm{CI}=95 \%$ confidence interval. 
raised for neoplasms of the skin $(S M R=137)$, genitourinary system $(\mathrm{SMR}=124)$, and lymphatic and haematopoietic tissue (SMR $=124)$, as well as benign neoplasms $(S M R=134)$. These were based on a small number of cases, however, and were not statistically significant. Half of the neoplasms of the genitourinary system $(n=4)$ were of the kidney (2.0 were expected, resulting in a non-significant SMR of 198). Staff employees had raised SMRs for neoplasms of the digestive system $(S M R=106)$ and skin $(\mathrm{SMR}=107)$, as well as benign neoplasms $(S M R=132)$. Again, none of these were statistically significant. Both for production and staff employees, the most common diagnosis among benign neo- plasms was lipoma followed by benign neoplasms of the colon.

Morbidity due to disorders of the nervous, respiratory, and digestive systems was further analysed for more specific categories of cause (tables 6,7 , and 8). Among disorders of the nervous system for production employees (table 6), only those of the eye and adnexa showed a statistically significant increase in morbidity $(S M R=153)$. This excess was primarily due to problems of refraction and accommodation. The Deer Park population had 18 events with such a diagnosis, whereas the rest of manufacturing (the total population excluding Deer Park) had only 1. All of these subjects were out of

Table 4 Observed morbidity and standardised morbidity ratios (SMRs) for employees by work classification 1981-8

\begin{tabular}{|c|c|c|c|c|}
\hline \multirow[b]{2}{*}{$\begin{array}{l}\text { Cause of morbidity } \\
\text { (ICD-CM 9th revision codes) }\end{array}$} & \multicolumn{2}{|l|}{ Production } & \multicolumn{2}{|l|}{ Staff } \\
\hline & $\begin{array}{l}\text { Observed } \\
\text { morbidity }\end{array}$ & $S M R(95 \% C I)$ & $\begin{array}{l}\text { Observed } \\
\text { morbidity }\end{array}$ & $S M R(95 \% C I)$ \\
\hline $\begin{array}{l}\text { All causes }(000-999) \\
\text { Infectious and parasitic diseases }(000-139) \\
\text { All neoplasms }(140-239) \\
\text { Endocrine, nutritional, and metabolic diseases }(240-279) \\
\text { Mental disorders }(290-319) \\
\text { Nervous system }(320-389) \\
\text { Heart disease }(390-399,410-419,420-429) \\
\text { Hypertension }(400-405) \\
\text { Cerebrovascular disease }(430-438) \\
\text { Haemorrhoids (455) } \\
\text { Other circulatory system disorders }(440-448,450-454,456-459) \\
\text { Respiratory system }(460-519) \\
\text { Digestive system (520-579) } \\
\text { Genitourinary system }(580-629) \\
\text { Skin and Subcutaneous tissue }(680-709) \\
\text { Musculoskeletal system (710-739) } \\
\text { Symptoms and ill-defined conditions }(780-799) \\
\text { Injury and poisoning }(800-999) \\
\text { Unknown and other causes }\end{array}$ & $\begin{array}{r}3315 \\
117 \\
73 \\
42 \\
97 \\
169 \\
65 \\
74 \\
3 \\
57 \\
33 \\
646 \\
350 \\
119 \\
96 \\
390 \\
113 \\
639 \\
232\end{array}$ & $\begin{array}{c}109(106-113) \\
102(84-122) \\
116(91-146) \\
116(84-158) \\
99(80-121) \\
120(103-140) \\
101(78-130) \\
144(113-181) \\
46(9-148) \\
149(113-194) \\
128(88-180) \\
108(100-117) \\
117(105-130) \\
110(92-132) \\
100(81-123) \\
100(91-111) \\
100(83-121) \\
97(87-105) \\
173(152-197)\end{array}$ & $\begin{array}{r}764 \\
15 \\
28 \\
13 \\
14 \\
39 \\
54 \\
16 \\
5 \\
15 \\
13 \\
79 \\
92 \\
33 \\
18 \\
58 \\
11 \\
78 \\
183\end{array}$ & $\begin{array}{c}97(90-104) \\
81(46-136) \\
92(61-134) \\
111(59-194) \\
78(43-133) \\
94(67-128) \\
96(72-126) \\
123(70-202) \\
76(25-187) \\
143(80-238) \\
110(59-192) \\
88(69-109) \\
92(74-113) \\
76(53-108) \\
115(68-184) \\
63(48-82) \\
59(29-107) \\
67(53-84) \\
189(162-218)\end{array}$ \\
\hline
\end{tabular}

Table 5 Observed morbidity and standardised morbidity ratios (SMRs) for neoplasms by work classification 1981-8

\begin{tabular}{|c|c|c|c|c|}
\hline \multirow[b]{2}{*}{ Cause of morbidity (ICD-CM 9th revision codes) } & \multicolumn{2}{|c|}{ Production } & \multicolumn{2}{|c|}{ Staff } \\
\hline & Obs & $S M R(95 \% C I)$ & Obs & $\operatorname{SMR}(95 \% C I)$ \\
\hline $\begin{array}{l}\text { All neoplasms } \\
\text { Digestive system }(150-159) \\
\text { Respiratory system }(160-165) \\
\text { Bone, connective tissue, and skin }(170-175) \\
\text { Genitourinary system (179-189) } \\
\text { Lymphatic and haematopoietic tissue (200-208) } \\
\text { Benign neoplasms (210-229) } \\
\text { All other neoplasms }\end{array}$ & $\begin{array}{r}73 \\
3 \\
3 \\
9 \\
8 \\
4 \\
31 \\
15\end{array}$ & $\begin{array}{r}116(91-146) \\
77(16-249) \\
73(15-238) \\
137(63-267) \\
124(54-252) \\
124(33-340) \\
134(91-191) \\
96(54-161)\end{array}$ & $\begin{array}{r}28 \\
5 \\
3 \\
3 \\
3 \\
2 \\
9 \\
3\end{array}$ & $\begin{array}{r}92(61-134) \\
106(34-262) \\
53(11-169) \\
107(22-343) \\
67(13-213) \\
91(10-379) \\
132(60-256) \\
83(17-265)\end{array}$ \\
\hline
\end{tabular}

Table 6 Observed morbidity and standardised morbidity ratios (SMRs) for nervous system disorders by work classification $1981-8$

\begin{tabular}{|c|c|c|c|c|}
\hline \multirow[b]{2}{*}{ Cause of morbidity (ICD-CM 9th revision codes) } & \multicolumn{2}{|c|}{ Production } & \multicolumn{2}{|c|}{ Staff } \\
\hline & Obs & $S M R(95 \% C I)$ & Obs & $S M R(95 \% C I)$ \\
\hline $\begin{array}{l}\text { All nervous system disorders } \\
\text { Peripheral nervous system (350-359) } \\
\text { Eye and adnexa (360-379) } \\
\text { Ear and mastoid process (380-389) } \\
\text { Other nervous system disorders (320-349) }\end{array}$ & $\begin{array}{r}169 \\
38 \\
71 \\
52 \\
8\end{array}$ & $\begin{array}{l}120(103-140) \\
100(71-138) \\
153(119-193) \\
110(83-145) \\
91(39-185)\end{array}$ & $\begin{array}{r}39 \\
8 \\
21 \\
7 \\
3\end{array}$ & $\begin{array}{r}94(67-128) \\
75(32-153) \\
112(69-173) \\
83(34-178) \\
75(15-238)\end{array}$ \\
\hline
\end{tabular}


Table 7 Observed morbidity and standardised morbidity ratios (SMRs) for respiratory disorders by work classification 1981-8

\begin{tabular}{|c|c|c|c|c|}
\hline \multirow[b]{2}{*}{ Cause of morbidity (ICD-CM 9th revision codes) } & \multicolumn{2}{|c|}{ Production } & \multicolumn{2}{|c|}{ Staff } \\
\hline & Obs & $\operatorname{SMR}(95 \% C I)$ & Obs & $S M R(95 \% C I)$ \\
\hline $\begin{array}{l}\text { All respiratory disorders } \\
\text { Acute infections }(460-466) \\
\text { Other diseases of upper tract }(470-478) \\
\text { Pneumonia and influenza }(480-487) \\
\text { Chronic pulmonary disease }(490-496) \\
\text { Pneumoconioses and other diseases due to external agents }(500-508) \\
\text { Other respiratory diseases }(510-519)\end{array}$ & $\begin{array}{r}646 \\
222 \\
120 \\
168 \\
100 \\
3 \\
33\end{array}$ & $\begin{array}{l}108(100-117) \\
110(96-125) \\
118(98-141) \\
97(83-113) \\
105(85-127) \\
200(41-646) \\
134(92-189)\end{array}$ & $\begin{array}{r}79 \\
21 \\
14 \\
28 \\
8 \\
0 \\
8\end{array}$ & $\begin{array}{r}88(69-109) \\
101(62-155) \\
90(49-152) \\
74(49-108) \\
68(30-139) \\
-\quad \\
186(81-382)\end{array}$ \\
\hline
\end{tabular}

Table 8 Observed and standardised morbidity ratios (SMRs) for digestive system disorders by work classification 1981-8

\begin{tabular}{|c|c|c|c|c|}
\hline \multirow[b]{2}{*}{ Cause of morbidity (ICD-CM 9th revision codes) } & \multicolumn{2}{|c|}{ Production } & \multicolumn{2}{|c|}{ Staff } \\
\hline & Obs & $S M R(95 \% C I)$ & Obs & $S M R(95 \% C I)$ \\
\hline $\begin{array}{l}\text { All digestive system disorders } \\
\text { Oral cavity, salivary glands, and jaws (520-529) } \\
\text { Oesophagus, stomach, and duodenum }(530-537) \\
\text { Appendicitis (540-543) } \\
\text { Hernia (550-553) } \\
\text { Non-infectious enteritis and colitis }(555-558) \\
\text { Other diseases of intestines and peritoneum }(560-569) \\
\text { Other diseases of digestive system }(570-579)\end{array}$ & $\begin{array}{r}350 \\
67 \\
72 \\
16 \\
46 \\
58 \\
57 \\
34\end{array}$ & $\begin{array}{l}117(105-130) \\
126(98-161) \\
122(96-154) \\
126(72-207) \\
82(60-110) \\
128(97-166) \\
142(108-185) \\
106(73-148)\end{array}$ & $\begin{array}{r}92 \\
5 \\
14 \\
6 \\
28 \\
8 \\
14 \\
17\end{array}$ & $\begin{array}{r}92(74-113) \\
88(28-216) \\
125(69-214) \\
94(34-213) \\
76(51-111) \\
138(60-281) \\
85(47-145) \\
96(56-155)\end{array}$ \\
\hline
\end{tabular}

Table 9 Age adjusted prevalence rates ${ }^{\star}$ for selected disease risk factors

\begin{tabular}{|c|c|c|c|c|}
\hline \multirow[b]{2}{*}{ Risk factors } & \multicolumn{2}{|c|}{ Production } & \multicolumn{2}{|l|}{ Staff } \\
\hline & $D P M C$ & $\begin{array}{l}\text { Total } \\
\text { manufacturing }\end{array}$ & $D P M C$ & $\begin{array}{l}\text { Total } \\
\text { manufacturing }\end{array}$ \\
\hline $\begin{array}{l}\text { Smoking } \\
\text { High blood pressure } \\
\text { Hypercholesterolaemia } \\
\text { Obesity }\end{array}$ & $\begin{array}{l}35 \cdot 0 \\
22 \cdot 6 \\
52 \cdot 9 \\
45 \cdot 8\end{array}$ & $\begin{array}{l}34 \cdot 7 \\
23 \cdot 7 \\
56 \cdot 1 \\
43 \cdot 7\end{array}$ & $\begin{array}{l}22 \cdot 7 \\
23 \cdot 9 \\
55 \cdot 8 \\
43 \cdot 1\end{array}$ & $\begin{array}{l}24 \cdot 1 \\
23 \cdot 8 \\
60 \cdot 3 \\
41 \cdot 0\end{array}$ \\
\hline
\end{tabular}

$\star$ Per 100 employees. Adjusted to the total manufacturing population using the direct standardisation method.

work for surgery to correct myopia or astigmatism (radial keratotomy).

None of the SMRs for the more detailed categories of respiratory disorders were significant. For production employees, pneumoconioses and other diseases due to external agents showed a raised SMR of 200, but this was based only on three cases. Two of these respiratory conditions were due to exposure to chlorine gas and one was due to exposure to butyl alcohol. A statistically non-significant SMR of 118 was seen for other diseases of the upper respiratory tract. About half of the events were caused by sinusitis and a third by a deviated nasal septum. Most of the morbidity events among other respiratory diseases $(S M R=134)$ were either not classified or due to pleurisy.

Further analysis of disorders of the digestive system indicated a statistically significant risk for other diseases of the intestines and peritoneum among production employees $(S M R=142)$. Half of these morbidity events were due to anal fissure, fistula, or abscess. Almost $40 \%$ were due to either irritable colon or were included in a catch all category for those not otherwise classified.

Table 9 shows the age adjusted prevalence for selected disease risk factors. Production employees from Deer Park had slightly higher rates of smoking $(35.0 \%)$ and obesity $(45.8 \%)$ than production employees from all manufacturing $(34.7 \%$ and $43.7 \%$ for smoking and obesity respectively). Among staff employees, Deer Park had a higher rate of obesity.

\section{Discussion}

Due to the small number of cases, neoplasms of lymphatic and haematopoietic tissue could not be broken down into more specific classifications. The increased risks of the certain categories of these neoplasms suggested by Marsh et al in a mortality study of employees at this same facility were not seen in this morbidity study. ${ }^{20}$ For production employees, four neoplasms of lymphatic and haematopoietic tissue morbidity episodes were observed and 3.2 
were expected, resulting in a statistically nonsignificant SMR of 124 . Included among these four episodes was one case of Hodgkin's disease, one case of lymphoma, one case of myeloid leukaemia, and one case of leukaemia with an unspecified cell type. There were no cases of lymphosarcoma during this period.

Marsh $e t$ al also reported an excess of cancers of the liver and biliary passage.$^{20}$ In our study the SMR for neoplasms of the digestive system was not raised $(S M R=77)$ among production employees. In fact, there were no cases of liver cancer. The neoplasms reported were primarily of the colon. Lastly, there were no reported absences due to neoplasms of the central nervous system.

Rates for hypertension were further calculated by race as Deer Park has a relatively larger population of black people $(12.5 \%$ for Deer Park and $9.6 \%$ for the comparison population), who have a higher risk of hypertension compared with white people. ${ }^{21}$ Among production workers, however, the SMRs were raised for both black and white workers (SMR $=119$ for black workers and SMR $=146$ for white workers). The SMR for white workers was statistically significant at $\mathrm{p}<0.05$.

Although the SMR for hypertension was raised, the rates for disease risk factors do not indicate a higher risk of hypertension in Deer Park than in the comparison population. This discrepancy may exist because the data for disease risk factors were taken from the last physical examination of each worker, most of which were performed during 1984-8. The morbidity data, however, cover absences since 1981 . In fact, after analysing data for 1981-4 and 1985-8, we found that the SMRs for hypertension decreased with time. This suggests improved treatment and control of hypertension over the study period.

Morbidity data used in this study were based primarily on reports from doctors, which could be confounded and affected by bias due to differences in patterns of medical practice and other regional factors. ${ }^{22-24}$ For example, the rate of use of medical care for haemorrhoid treatment showed a 26 -fold difference between states with the highest and lowest rates of use. ${ }^{22}$ Utilisation patterns of employee health care could also influence the morbidity outcome; therefore, the appropriateness of comparisons based on these data must be carefully evaluated. The statistically significant increases of risk seen among this study population for certain medical conditions do not appear to be associated with occupational factors. The differences in the morbidity experience of Deer Park and all manufacturing are likely to be due to other factors, such as area medical practice patterns (that probably account for the much higher rates of radial keratotomy and haemorrhoidectomy among Deer Park employees), climate (which may affect respiratory problems such as sinusitis), dietary habits (which may aggravate digestive problems and haemorrhoids), and other factors of lifestyle. In fact, our results do show that Deer Park employees had higher rates of obesity.

In this study, we used the total Shell manufacturing population as the internal comparison group to facilitate comparisons between the morbidity experience of each location. No potential bias is associated with the "healthy worker effect" in this type of study design. A problem with the method, however, is that the reported SMRs may be over or underestimated. Also, this study was based on a small number of person-years, which may have led to rather imprecise estimates of morbidity ratios, as reflected in wide confidence intervals.

Data on morbidity outcome from health surveillance in the present study were limited to the active employees or those who retired during the study period. Persons who left Deer Park for reasons other than retirement or those who retired before 1 January 1981 could not be studied. In extrapolating results of this study to the health state of former employees, the potential impact of the long latency of certain diseases and the possible retirement of former employees due to health reasons must be considered. This was not a major drawback here because, among employees who retired before age 65 , around $10 \%$ of both Deer Park and the comparison populations had long term (two months or longer) illness related absence three months before their retirement. As only one prevalence event per employee was counted in any diagnostic category, the analysis does not take into account the severity of chronic conditions or truly new incidence cases. This applies to both the Deer Park and comparison populations, however, and should not bias the results. Furthermore, only persons who stayed out of work for six days or more were included in the study. Short term illnessabsence (those less than six days) patterns could be different between locations.

Health surveillance is one of the important components of occupational epidemiology. This type of analysis will likely improve the quality and understanding of these data. The findings are useful in setting priorities for medical programmes and directing efforts such as health education programmes and other strategies for disease prevention. Also, examination of health surveillance data can quickly identify areas of concern and can be a useful prelude to the design of more specific epidemiological studies.

1 Tabershaw-Cooper Associates, Inc. $A$ mortality study of petroleum refinery workers. Project $\mathrm{OH}-1$. Washington: Submitted to the American Petroleum Institute, 1974 (unpublished).

2 Hanis NM, Holmes TM, Shallenberger LG, et al. Epidemiologic study of refinery and chemical plant workers. J Occup Med 1982;24:203-12.

3 Wen CP, Tsai SP, McClellan WA, et al. Long-term mortality study of oil refinery workers. I. Mortality of hourly and salaried workers. Am J Epidemiol 1983;118:526-42. 
4 Divine BJ, Barron V, Kaplan SD. The Texaco Mortality Study. I. Mortality among refinery, petrochemical, and research workers. J Occup Med 1985;27:445-7.

5 Wong $\mathrm{O}$, Morgan RW, Bailey WJ, et al. An epidemiological study of petroleum refinery employees. $\mathrm{Br} J$ Ind Med 1986;43:6-17.

6 Rushton L, Alderson MR. An epidemiological survey of eight oil refineries in Britain. Br J Ind Med 1981;38:225-34.

7 Wongsrichanalai C, Delzell E, Cole P. Mortality from leukemia and other diseases among workers at a petroleum refinery. J Occup Med 1989;31:106-11.

8 Delzell E, Austin H, Cole P. Epidemiologic studies of the petroleum industry. Occupational Medicine: State of the Art Reviews 1988;3:455-74.

9 Wong O, Raabe GK. Critical review of cancer epidemiology in petroleum industry employees, with a quantitative metaanalysis by cancer site. Am J Ind Med 1989;15:283-310.

10 Medical Information Systems Roundtable. J Occup Med 1982;24:781-866.

11 Schottenfeld D, Warshauer MR, Zauber AG, et al. A prospective study of morbidity and mortality in petroleum industry employees in the United States - a preliminary report. In: Peto R, Schneiderman M, eds. Banbury Report 9: Quantification of Occupational Cancer. Cold Spring Harbor, New York: Cold Spring Harbor Laboratory, 1981:247-65.

12 Brenner FE, Bond GG, McLaren EA, Cook RR. Morbidity among employees engaged in the manufacture or formulation of chlopyrifos. BrJ Ind Med 1989;46:133-7.

13 Bond GG, Ott MG, Brenner FE, Cook RR. Medical and morbidity surveillance findings among employees potentially exposed to TCDD. Br J Ind Med 1983;40:318-24.

14 Tsai SP, Cowles SR, Tackett DL, Barclay MT, Ross CE.
Morbidity prevalence study of workers with potential for exposure to epichlorohydrin. Br J Ind Med 1990;47:392-9.

15 Chen JL, Fayerweather WE. Epidemiologic study of workers exposed to titanium dioxide. J Occup Med 1988;30:937-42.

16 Joyner RE, Pack PH. The Shell oil company's computerized health surveillance system. J Occup Med 1982;24:812-4.

17 Commission on Professional and Hospital Activities. International classifications of diseases, 9 th revision, clinical modification. Ann Arbor, Mich: CPHA, 1978.

18 National Institutes of Health Consensus Development Panel on the Health Implications of Obesity. Health implications of obesity: National Institute of Health consensus development - statement. Ann Intern Med 1985;103:1073-7.

19 Bailar JC, Ederer F. Significance factors for the ratio of a Poisson variable to its expectation. Biometrics 1964;20:639-43.

20 Marsh GM, Enterline PE, McCraw D. Mortality patterns among petroleum refinery and chemical plant workers. $\mathrm{Am} \mathrm{J}$ Ind Med 1990;19:29-42.

21 Hypertension Detection and Follow-up Program Cooperative Group. Race, education and prevalence of hypertension. Am J Epidemiol 1977;106:351-61.

22 Chassin MR, Brook RH, Park RE, et al. Variations in the use of medical and surgical services by the Medicare population. $N$ Engl J Med 1986;314:285-90.

23 Knickman JR, Foltz AM. Regional differences in hospital utilization. Med Care 1984;22:971-86.

24 Wolff N. Professional uncertainty and physician medical decision-making in a multiple treatment framework. Soc $S c i$ Med 1989;28:99-107.

Accepted 4 November 1991 